\section{ECONOMICS}

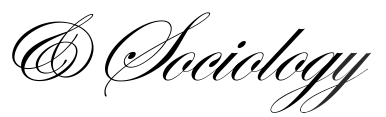

Aliyev, K., Ismayilov, A., Gasimov, I., \& Isayeva, A. (2021). Unhappy moves? Assessing the link between life (dis)satisfaction and intention to emigrate in Azerbaijan. Economics and Sociology, 14(3), 127-145. doi:10.14254/2071-

789X.2021/14-3/7

\title{
UNHAPPY MOVES? ASSESSING THE LINK BETWEEN LIFE (DIS)SATISFACTION AND INTENTION TO EMIGRATE FROM AZERBAIJAN
}

\author{
Khatai Aliyev \\ Azerbaijan State University of \\ Economics (UNEC), Baku \\ Engineering University, Khirdalan, \\ ASERC, Baku, Azerbaijan \\ E-mail:kbatai.aliyev@unec.edu.ar \\ ORCID 0000-0001-8161-6269
}

\author{
Altay Ismayilov \\ Azerbaijan State University of \\ Economics (UNEC), Baku, \\ Azerbaijan \\ E-mail: \\ altay.ismayilov@unec.edu.az \\ ORCID 0000-0003-0716-7076 \\ Ilkin Gasimov \\ Baku Engineering University, \\ Khirdalan, Ministry of Economy of \\ the Republic of Azerbaijan, Baku, \\ Azerbaijan, UNEC Azerbaijan \\ State University of Economics \\ (UNEC), Baku, Azerbaijan \\ E-mail:ilgasimov@beu.edu.az \\ ORCID 0000-0003-1388-7571
}

\author{
Asmar Isayeva \\ Azerbaijan State University of \\ Economics (UNEC), Baku, \\ Azerbaijan \\ E-mail:asmarisaveva@gmail.com \\ ORCID 0000-0003-2356-1348
}

Received: April, 2021

1st Revision: August, 2021

Accepted: September, 2021
ABSTRACT. Illegal international emigration has been one of the biggest challenges during the last decade. Intention to emigrate is a step before making an emigration decision and releasing the aspirations. The issue is crucial for both sending and receiving country, depending on the immigrant's life satisfaction whether it is a "happiness" or an "unhappiness" move. The study aims to investigate the impact of life (dis)satisfaction on intention to emigrate from the Muslim-majority society - Azerbaijan by using the representative survey data of 1317 respondents $\left(\mathrm{n}_{\text {male }}=718, \mathrm{n}_{\text {female }}=599, \mathrm{Mean}_{\text {age }}=32.62, \mathrm{SD}_{\text {age }}=11.75\right)$ and Ordinary Least Squares (OLS), Robust Least Squares and Ordered Logit estimation methods. Results altogether support the "unhappiness move" hypothesis. Emigration intention in Azerbaijan is very high among dissatisfied people, especially among the youth and males. Intention to emigrate decreases in response to positive change in selfreported happiness and age increase. Considering its utmost importance, the Azerbaijani government should implement policies targeted at enhancing citizens' life satisfaction, particularly among the youth. Research findings are also highly useful for the potential emigrant receiving countries to design the migration policy.

DOI: $10.14254 / 2071-$

789X.2021/14-3/7 
JEL Classification: F22, I31, $\mathrm{J} 18$
Keywords: life satisfaction, intention to emigrate, unhappy move, migrant sending countries, migrant receiving countries, migration policy, Azerbaijan

\section{Introduction}

From the dawn of history, there were various ideas viewing migration as a complex and comprehensive structure within economic and social spheres. Both microeconomic and macroeconomic considerations on the migration decision determined the ways to engage and understand the cores and fundamentals that force people to emigrate. Concerning this point, we can infer that decreasing life satisfaction in a home country or increasing aspirations of individuals regarding their lives force them to migrate, find more and somehow catch the "happiness" (Otrachshenko \& Popova, 2014). In this context, various scholars underline that emigration intentions trigger migration flows (Docquier et al., 2014; Bertoli \& Ruyssen, 2018; Tjaden, Auer \& Laczko, 2019). Carling and Schewel (2018) have underlined emigration intentions to be an intermediary stage towards the realization of emigration.

In Carling (2017), a model of the mechanism, which results in migration, is presented (see fig.1). Conditions and prospects in a home country affect the life aspiration of individuals, which stimulates them to make a change. Therefore, migration aspirations are also within the list of expected responses in such a case.

Regardless the fact that the migration intention successfully ends with emigration or not, the model displays a solid linkage. In this context, it could be expected that dissatisfied individuals should be much more vulnerable to migration aspirations. However, Ivlevs (2015) underlines the notion of "happiness drain" and argues that increasing life satisfaction makes individuals more prone to emigration. Therefore, this issue requires a detailed empirical investigation on the within-country basis.

In the emigration history of Azerbaijani citizens, the breakup of the Soviet Union in 1991 plays a crucial role, which changed the political map of the world and highly influenced the economic and social lives of the population in the former member countries. According to the official statistics, approximately nine million individuals in the post-Soviet region left one country and moved to another one for living there within the period 1991-2000 (Radnitz, 2006). Another critical factor affecting the emigration decision was new opportunities for citizens of former Soviet states. Obviously, the Soviet Union was a closed box with strict rules, which had fewer possibilities to move to other countries for better living conditions. After the collapse of Soviet Union, barriers caused the citizens to emigrate to different parts of the world (Papapanagos \& Sanfey, 2001).

As a former Soviet Union member, Azerbaijan had faced with political instability, economic difficulties, and social tensions after the dissolution of the Soviet Union. In addition, war with Armenia over the Nagorno-Karabakh region, as a result, loss of $20 \%$ territory with more than 1 million refugees and internally displaced persons also negatively affected the overall situation in Azerbaijan, which increased emigration aspirations and the number of emigrants. Though the emigration process in Azerbaijan started from the 1980's, within the first years of independence, most of the emigrants were Russian and Russianspeaker citizens of Azerbaijan who moved to Russia and other CIS countries (Allahveranov, Aliyeva \& Sadigov, 2012). 


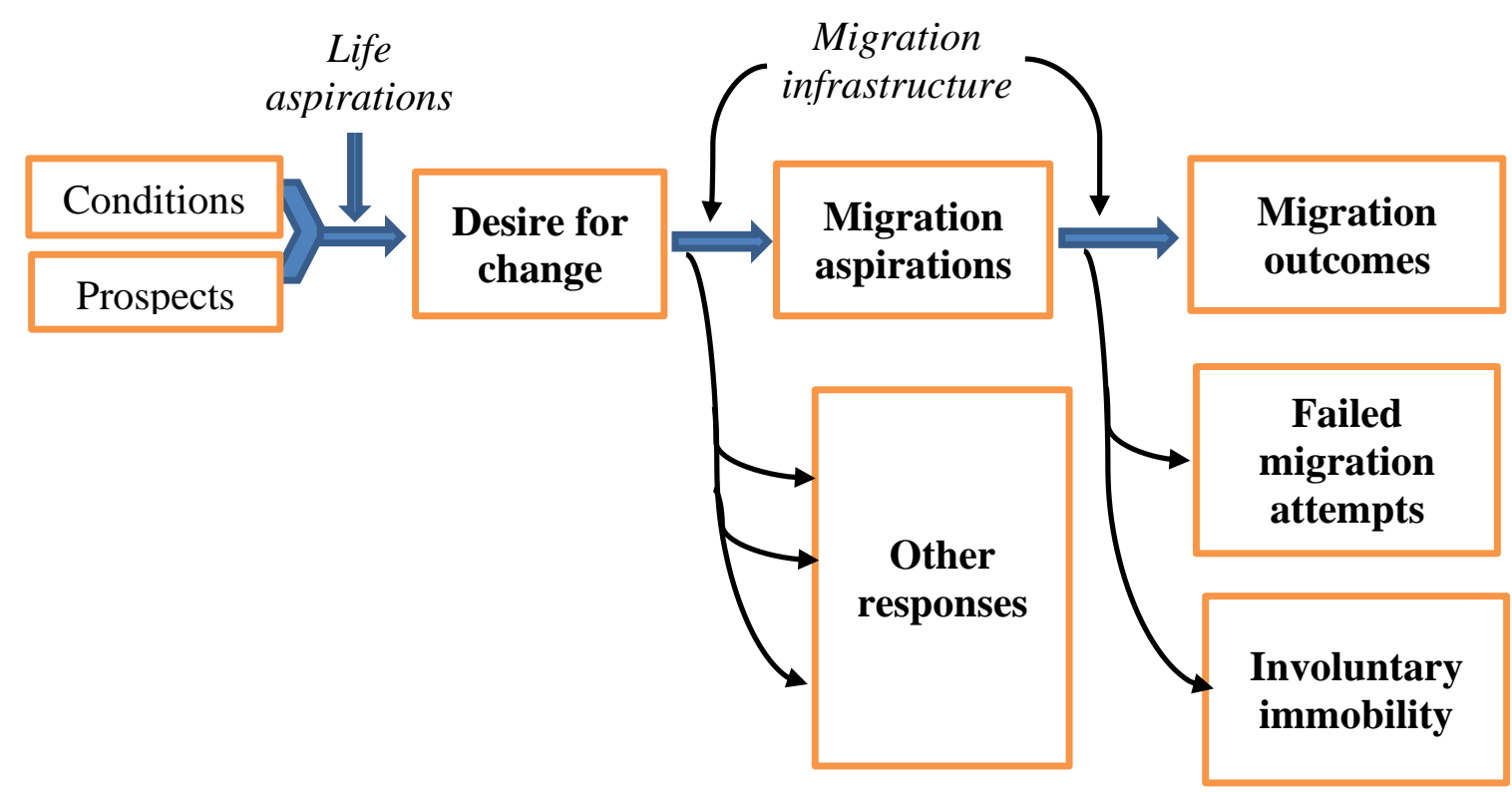

Figure 1. A model of the mechanisms that produce migration Source: Carling (2017)

The second wave of the emigration process in Azerbaijan started after the second part of 1994. Though during the first years Azerbaijanis generally migrated to Russia and other former Soviet countries, afterwards Turkey, Iran and some Arabian countries were main direction of emigration (Iunusov, 2003).

Progress in the economy, achievement of political stability and extraction of natural resources improved the living standards in Azerbaijan. Large oil revenues gave the government the opportunity to implement a number of socio-economic programs to increase the population's welfare. All the positive facts also cause the migration outflow to decline after the 2000s. According to official statistics presented by the State Statistical Committee number of people permanently leaving Azerbaijan for other countries was 137.9 thousand persons in 1990, 16 thousand persons in 1995, 9.9 thousand persons in 2001, 2,9 thousand in 2005, which is accepted as the launch of an oil boom period in Azerbaijan (Aliyev \& Gasimov, 2018). The oil boom period covering 2005-2014 was accompanied by a decrease of emigrants from Azerbaijan. Hence, in 2014 number of emigrants was 0.8 thousand.

The third wave of the emigration process from Azerbaijan can be explained by worsening socio-economic conditions followed by a sharp decline of oil price in world markets at the end of 2014, accompanied by devaluation of the national currency (the currency was deprecated from $1 \mathrm{USD}=0.78 \mathrm{AZN}$ to $1 \mathrm{USD}=1.7 \mathrm{AZN}$ ) and inflation. So that, devaluations of the national currency against USD in February and December of 2015 resulted in decreased purchasing power of population and wages in real terms, which increased the number of people willing to continue their remaining lives abroad. Official statistics reveal that the number of emigrants increased from 0.8 thousand people to 1.6 thousand in 2015, 1.7 thousand persons in 2016 and reached 1.9 thousand persons in 2017. Differently from the first wave of emigration, now main directions were countries with higher living standards and quality of life, such as European countries and the United States of America.

According to different sources, approximately $16 \%$ of the total population of Azerbaijan lives in other countries leading by Russia with $60 \%$ (Allahveranov, Aliyeva \& Sadigov, 2012). However, it should also be noted that main directions for asylum application 
by Azerbaijani refugees were European countries, the USA and Canada. Therefore, in 2018, 3179 persons applied for asylum in different countries leading by Germany, France and Sweden with $83 \%$ rejection rates. Spain, Canada and the United Kingdom are top countries with $100 \%, 62.3 \%$ and $47,4 \%$ acceptance rate, respectively (Worlddata, 2020).

Therefore, there is evidence of increasing emigration aspirations and many failed emigration attempts in Azerbaijan since early 2015, which is a crucial issue for Western countries and the general context. However, there is an absence of publicly available scientific research on the determinants of increasing emigration aspirations. Current research partially fills the gap by investigating the association between emigration aspirations and happiness in the country by employing unique raw survey data. Here, the primary hypothesis is that emigration aspirations in Azerbaijan are dissatisfaction motivated especially among youth and males which should support the validity of "unhappy moves" hypothesis.

The remaining part of the article is structured as follows. Section I review the main results of existing studies. Section II discuss the methodological approach while primary research findings are presented in the third section.

\section{Literature review}

Within the traditional framework, migration is considered the consequence of failed economic and social development and low institutional capacity. However, recent studies reveal antagonistic considerations on intentions to migrate. Once people benefit from the rising economic and social development within a country, psychologically, their desires to get more and more and going beyond - out of the box increases. Thus, for instance, advancing education in a developing country results in greater aspirations and increasing motives for poor families to migrate to the countries that offer desirable opportunities, which is the investment approach to the migration decision (Clemens, 2017). The effect of seeking better educational opportunities and the willingness of educated people to migrate were in the heart of various studies (Glover, 2001; Lapshyna \& Düvell, 2015; Ivlevs, 2015; Simpson, 2017; Ozaltin et al., 2019) as the core determinant of the migration decision. Both of these findings share the common approach on the existence of higher migration intention of well-educated people, as migration creates a pool of opportunities for them (Migali and Scipioni, 2018). However, acting on these opportunities is not only about being educated, sometimes education may not be sufficient to stimulate migration decision, and in this case, personality has its paramount speech (Bloeser et al., 2012).

Institutional weaknesses, such as corruption in developing countries, are also push factors to emigrate. By diminishing the returns on education, corruption acted primarily emigrate, especially among skilled workers (Dimant, Krieger and Meierreks, 2013; Cooray and Schneider 2016). Authors such as Gugushvili (2011) and Hiskey, Montalvo and Orces (2014) found a negative link between democracy level and intention to emigrate for Azerbaijan and 22 Latin American countries, respectively.

The conceptual framework on the difference between the migration aspirations and capability of realizing migration also supports these findings (De, 2010; Carling \& Schewel, 2017). Although educational level can be muted by the extraversion, which overcomes cultural obstacles, openness for new adventures comes with increasing education (Canache et al., 2013). According to the preceding findings, these two essential elements of human nature are essential elements of willingness to migrate. Most probably, the perfect match of a potential migrant is to be the person who is young, male, well educated, has strong external networks in a destination country and in search of future opportunities for developing further. This fact was also endorsed afterwards with the inclusion of unemployment and being foreign-born (Migali \& Scipioni, 2018). Moreover, Manchin and Orazbayev (2018) argue that 
if a potential migrant has not any strong network in a host country, then he/she will be vulnerable in terms of further financial assistance and they will fail in their attempts in restoring their life satisfaction.

Although individual well-being is crucial in all respects, a country's macroeconomic conditions have its undeniable prominence. Macroeconomic indicators of countries and the increasing social gap among citizens lead to increasing migration intentions (Simpson, 2017; Glover et al., 2001; Black et al., 2005). In recent studies, migration intentions evaluated based on the country's income level. According to Clemens (2014), migration intentions rise with the increasing level of individual income in low-income countries, while the relationship is vice versa in high-income countries. Thus, intention to emigrate increases in response to the decreasing level of individual income (Clemens, 2014).

In the current migration literature, the majority of the studies investigate the impact over life satisfaction of respondents after the migration happened (De Jong, Chamratrithirong \& Tran, 2002; Ying, 2005; Kuo \& Roysircar, 2006; Cárdenas, Di Maro \& Sorkin, 2009; Bartram, 2011; Melzer, 2011; Nowok et al., 2013; Olgiati, Calvo \& Berkman, 2013; Lönnqvist et al., 2015; Angelini, Casi, and Corazzini, 2015; Switek, 2016 among others) while the studies for pre-emigration is relatively limited in number and scope (Polgreen \& Simpson, 2011; Graham \& Markowitz, 2011; Cai et al., 2014; Otrachshenko \& Popova, 2014; Chindarkar, 2014; Ivlevs, 2015; Steiner, 2019; Hăisan, Goschin \& Avornicului, 2017; Orosová et al., 2018; Szilasi \& Halász, 2018; Taburga, 2018).

Nevertheless, as Ivlevs (2015) underlines, examining the relationship between subjective well-being and emigration intention has important policy implications for both migrant sending and receiving countries. Considering the increasing role of subjective wellbeing as a key variable to measure individual welfare and societal progress by governments (Diener et al. 2009), policy changes affecting happiness in a sending country will affect emigration decisions if there is a strong relationship and migration flow (Ivlevs, 2015). On the other hand, happy people are more creative and sociable as well as healthier and productive (Ivlevs, 2014). Hence, migrant-receiving countries are interested in accepting "happy" ones who will "put less pressure on the welfare state and integrate more successfully into the host society" while sending country policymakers should be "concerned about the outflow of happy people, as this may deprive them of the many positive externalities that happiness is associated with" (Ivlevs, 2015, p.336).

In a country level study, Polgreen and Simpson (2011) had revealed that the highest emigration rates belong to the least and the happiest countries. However, a negative relationship is found in Central and Eastern Europe (Otrachshenko \& Popova, 2014), and Latin America (Graham \& Markowitz, 2011; Chindarkar, 2014). Employing Gallup World Survey data for 116 countries, Cai et al. (2014) also found the existence of a negative association between life satisfaction and emigration intentions. On the contrary, Ivlevs (2014, 2015) concluded with positive association: an increase in life satisfaction increases the probability of reporting emigration intention.

To our best knowledge, there is no any empirical research on understanding the determinants of emigration intentions in Azerbaijan and its association with the level of life satisfaction of individuals. However, considering its vulnerable economy (high-level elasticity to oil prices, weak economic structure) and different kinds of institutional problems, Azerbaijan may have severe emigration challenges in the near future. Recent dynamics also support this claim. Therefore, current research has addressed an important issue for Azerbaijan and the potential host countries. 


\section{Methodological approach}

\section{Sampling and research methodology}

Within cross-sectional data analyses framework, the research employs a survey dataset by ASERC (2018). In a larger context, the target group is constituted by the active labour force of the Azerbaijan Republic. However, to consider job-related factors in empirical estimations, the target group is limited to be employed individuals in the Republic. Note that the corresponding dataset represents a random and representative sample of the target group. The total number of survey participants is 2208 (1093 males, 1115 females). Excluding students, housewives, unemployed and retired (not working) people, 1317 respondents left (718 males, 599 females), varying from 17 to 77 years old $(M=32.618, S D=11.75)$. Among respondents, $16.85 \%$ are a comprehensive school, and $13.52 \%$ are college graduates, $45.71 \%$ has a bachelor, $18.53 \%$ has a master, and $5.39 \%$ has $\mathrm{PhD}$ degrees. In terms of marital status structure, $42.06 \%$ are single, $3.42 \%$ are engaged, $50.27 \%$ are married, and $4.25 \%$ are widowed/divorced.

The survey is conducted online and paper-based (face-to-face) at the same time, during October-December, 2018. Overall, 53.5\% of respondents represent Baku (the capital and largest city of Azerbaijan), and remaining responses were obtained from other country regions.

\section{Variables}

Definitions and measurement scale of the dependent (intention to emigrate (IE)), main independent (life satisfaction (LS)) and control variables are given below.

Intention to emigrate (IE) indicates the willingness of the respondent to emigrate. In the survey, respondents are asked to express their agreement level with the statement that "I would like to emigrate and live in a foreign country", as a multiply choice question. Answer options include "totally agree (7)", "agree (6)", "slightly agree (5)", "neutral (4)", "slightly disagree (3)", "disagree (2)", "strongly disagree (1)". Later, the responses transformed into quantitative form, changing from 1 to 7 , respectively. The distribution of IE by gender, age group and education level is given in Appendix A.

Life satisfaction (LS) is the main independent variable, represent the self-reported happiness of the respondents. To measure LS of the respondents, the Satisfaction With Life Scale (SWLS) methodology of Pavot and Diener (1993) is employed. Following the SWLS methodology, Respondents are asked to state their agreement level to 5 different statements, with the answer choices changing from strongly agree to strongly disagree, quantified like IE. The statements are (see Pavot \& Diener, 1993, p.172): (1) In most ways, my life is close to my ideal, (2) the conditions of my life are excellent, (3) I am satisfied with my life, (4) so far I have gotten the important things I want in life, and (5) if I could live my life over, I would change almost nothing.

The value of LS is obtained as the total sum of the scores to each statement, changing between 5 as the minimum (if a respondent selects "strongly disagree" to all statements) while the maximum value is 35 (if a respondent chooses "strongly agree" to all statements). According to this methodology: $5 \leq L S \leq 9$ means extremely dissatisfied; $10 \leq L S \leq 14$ means dissatisfied; $15 \leq L S \leq 19$ means slightly dissatisfied; $L S=20$ means to be neutral neither dissatisfied nor satisfied; $21 \leq L S \leq 25$ means slightly satisfied; $26 \leq L S \leq 30$ means satisfied; $31 \leq L S \leq 35$ means extremely satisfied. 
The list of control variables andjob-related factors are: Salary represents monthly after-tax earnings of each employee, measured in AZN. Work_hour denote the amount of weekly average work hour of each worker. Hourly salary is used in empirical estimations, denoted as $\ln (H S)_{i}$. HS for each respondent is calculated as $\frac{\text { Salary }}{4 * \text { work_hour }}$. Approximate monthly amount of working hours is calculated with this logic. Agreement with job conditions (AJC) is a proxy for job satisfaction in terms of overall conditions, measured as a 7 Likert scale where 1 means strongly disagree while 7 stands for strongly agree. More precisely, an increase in AJC implies higher job satisfaction.

Individual specific factors are taken into account by including age (denote age of a respondent), female (a dummy variable, equals 1 if the respondent is female, 0 otherwise), no_child (a dummy variable, equals 1 if the respondent has no child, 0 otherwise), education level dummies (School gets 1 if the highest level of educational attainment is graduation from comprehensive schools, 0 otherwise; College equals 1 if the person has college degree only after school graduation, 0 otherwise; Bachelor is taken as a reference group, equals 1 if the respondent has bachelor degree as the highest, 0 otherwise; Master equals 1 if the respondent is master degree holder as the highest, 0 otherwise; $\mathrm{PhD}$ gets 1 if the person has $\mathrm{PhD}$ degree, 0 otherwise), and marital status related dummies (Single is included as the reference group, equals 1 if the person is single, 0 otherwise; Engaged gets 1 if the person is a step closer to be married (has fiancé), 0 otherwise; Married equals 1 if the respondent is married, 0 otherwise; Widowed gets 1 if the person is divorced or widowed, 0 otherwise).

\section{Empirical model}

The base model for empirical estimations includes IE as the dependent $\left(Y_{i}\right)$, and LS as the main independent variable $\left(\mathrm{X}_{i}\right)$ in addition to job-specific $\left(\mathrm{Z}_{k, i}\right)$ and individual-specific $\left(\psi_{l, i}\right)$ control variables. Job-specific factors are limited to hourly salary and agreement level with overall job conditions, while individual-specific factors cover gender status, age, marital status, having a child or not, and educational attainment level. The initial model specification is as follows:

$$
Y_{i}=\alpha_{0}+\alpha_{1} * \mathrm{X}_{i}+\sum_{k=1}^{n} \beta_{k} * \mathrm{Z}_{k, i}+\sum_{l=1}^{m} \gamma_{l} * \psi_{l, i}+u_{i}
$$

Where $\alpha, \beta$, and $\gamma$ denote regression coefficients. $u$ is the error term. $i$ stand for ith observation in the sample.

Here, three estimation methods - Ordinary Least Squares (OLS), Robust Least Squares (LS), and Ordered Logit are employed for the robustness of results. Especially, Ordered Logit is more reliable when the dependent variable is categoric with finite order. Therefore, three different models are estimated. For OLS and Robust Least Squares (LS), the elasticity ( $\ln \Leftarrow \ln$ ) relationship is estimated, while in Ordered Logit, the dependent variable is linear and LS is included in natural logarithm.

Finally, considering Ivlevs (2015), the existence of a non-linear (parabolic) relationship is also examined. Ramsey-Reset test result displayed statistically significant inverse U-shaped causality from LS to IM for OLS and Robust Least Squares (LS). Therefore, final model specifications for OLS and Robust Least Squares (LS) is developed into the following form:

$$
\ln (Y)_{i}=\alpha_{0}^{\prime}+\alpha_{1}^{\prime} * \mathrm{X}_{i}+\alpha_{2}^{\prime} * X_{i}^{2}+\sum_{k=1}^{n} \beta_{k}^{\prime} * \mathrm{Z}_{k, i}+\sum_{l=1}^{m} \gamma_{l}^{\prime} * \psi_{l, i}+u_{i}^{\prime}
$$


Within job-related factors, hourly salary is included in natural logarithm form $\left(\ln \left(\frac{\text { salary }}{\text { work_hour }}\right)_{i}\right)$. Ramsey-Reset test displays inverse U-shaped causality from age to IM while employing OLS and Robust Least Squares (LS) methods in the estimation process. Therefore, age in natural logarithm form included twice in equation (2), as $\ln (a g e)_{i}$ and $\ln (\text { age })_{i}^{2}$.

\section{Conducting research and results}

\subsection{Application of multiple linear regression analysis}

Before the regression analysis, descriptive statistics were performed. Table 1 tabulates descriptive statistics of all variables. Here, the mean value of IE and LS is highly noticeable. The average emigration intention of all respondents is approximately 4.95 out of a maximum 7. A quite high level of emigration intention can be explained by relative low life satisfaction among the individuals. Thus, the average LS value for the whole sample is less than the neutral $(L S=20$ ) level. Initial evidence for the existence of negative causality from LS to IE is seen in Figure 2.

Table 1. Descriptive statistics of variables

\begin{tabular}{lccccc}
\hline \multicolumn{1}{c}{ Variable } & No. of obs. & Mean & Minimum & Maximum & Std. Dev. \\
\hline IE & 1302 & 4.9485 & 1 & 7 & 2.129 \\
\hline LS & 1305 & 19.076 & 5 & 35 & 7.007 \\
\hline Work_hour & 1194 & 43.172 & 10 & 112 & 18.46 \\
\hline Salary & 1169 & 662.12 & 75 & 6734 & 646.8 \\
\hline AJC & 1279 & 4.8467 & 1 & 7 & 1.716 \\
\hline Age & 1312 & 32.618 & 17 & 77 & 11.75 \\
\hline No_child & 1317 & 0.5095 & 0 & 1 & 0.500 \\
\hline School & 1317 & 0.1685 & 0 & 1 & 0.375 \\
\hline Collage & 1317 & 0.1352 & 0 & 1 & 0.342 \\
\hline Bachelor & & & Base group & \\
\hline Master & 1317 & 0.1853 & 0 & 1 & 0.388 \\
\hline PhD & 1317 & 0.0539 & 0 & 1 & 0.226 \\
\hline Female & 1317 & 0.454 & 0 & 1 & 0.498 \\
\hline Engaged & 1317 & 0.034 & 0 & 1 & 0.182 \\
\hline Single & & & Base group & \\
\hline Married & 1317 & 0.503 & 0 & 1 & 0.202 \\
\hline Widowed & 1317 & 0.043 & 0 & \\
\hline
\end{tabular}

Source: Authors' own calculations

Analyzing the data show that intention to emigrate is higher among dissatisfied respondents than relatively more satisfied ones. Among extremely dissatisfied respondents (139 participants), the average emigration intention is 5.942, while the score decreases to 5.497 for dissatisfied people (239 respondents) and 5.185 for the slightly dissatisfied group. Downward tendency continues as life satisfaction rises. 


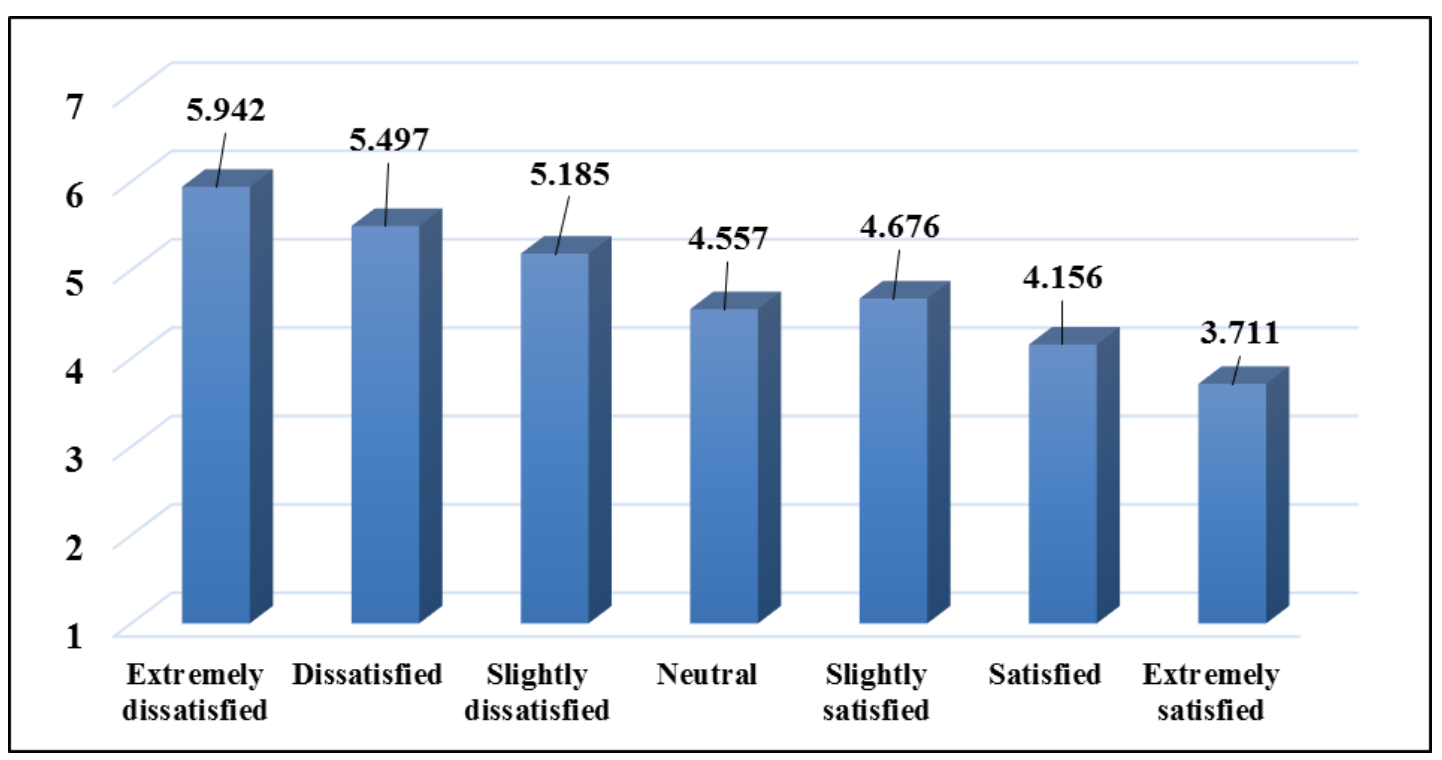

Figure 2. Life satisfaction vs intention to emigrate Source: Authors' own creation

\subsection{Empirical results}

To get more reliable results and to be able to compare estimation outcomes from different methods, all findings are given in the same table. Below, Table 2 tabulates estimation results from OLS, Robust Least Squares (LS) and Ordered Logit.

Despite estimation procedure difference in each method, the results mainly support each other. Especially, regression coefficients from OLS and Robust Least Squares (LS) are almost identically the same. Both of these methods conclude with the existence of a nonlinear, inverse U-shaped association between LS and IE. Corresponding coefficients are statistically significant at $5 \%$ level of significance $(p<0.05)$. On the contrary, the Ordered Logit method reveals a significant negative relationship. At this point, the threshold value of LS at which marginal impact over IE is zero should be calculated for a better understanding of empirical results.

To find out the threshold point of the OLS equation, the first derivative is found as follows (see the second column of Table 2):

$$
\begin{gathered}
\frac{\partial \ln (I E)_{i}}{\partial \ln (L S)_{i}}=0.8352-2 * 0.2101 * \ln (L S)_{i}=0 \\
\ln (L S)_{i}=\frac{0.8352}{0.4202}=1.988 \\
L S=\exp (1.988)=7.301
\end{gathered}
$$

Similarly, the threshold point for the equation by Robust LS can also be calculated (see the third column of Table 2):

$$
\begin{gathered}
\frac{\partial \ln (I E)_{i}}{\partial \ln (L S)_{i}}=0.8076-2 * 0.1979 * \ln (L S)_{i}=0 \\
\ln (L S)_{i}=\frac{0.8076}{0.3958}=2.04
\end{gathered}
$$




$$
L S=\exp (2.04)=7.69
$$

Table 2. Estimation results

\begin{tabular}{|c|c|c|c|}
\hline Independent variables & $\mathbf{O L S}^{\mathbf{a}}$ & Robust $\mathbf{L S}^{\mathbf{b}}$ & Ordered Logit ${ }^{\mathrm{c}}$ \\
\hline $\ln (L S)_{i}$ & $\begin{array}{c}0.8352^{* *} \\
(0.390)\end{array}$ & $\begin{array}{c}0.8076^{* *} \\
(0.326)\end{array}$ & $\begin{array}{c}-1.3124^{* * *} \\
(0.152)\end{array}$ \\
\hline $\ln (L S)_{i}^{2}$ & $\begin{array}{c}-0.2101^{* * *} \\
(0.073) \\
\end{array}$ & $\begin{array}{c}-0.1979^{* * *} \\
(0.061)\end{array}$ & - \\
\hline $\ln (H S)_{i}$ & $\begin{array}{c}-0.0067 \\
(0.023)\end{array}$ & $\begin{array}{l}-0.0007 \\
(0.019)\end{array}$ & $\begin{array}{c}-0.0353 \\
(0.075)\end{array}$ \\
\hline$A J C_{i}$ & $\begin{array}{c}-0.0268^{* * *} \\
(0.011)\end{array}$ & $\begin{array}{c}-0.0234^{* *} \\
(0.009)\end{array}$ & $\begin{array}{c}-0.0818^{\text {** }} \\
(0.037)\end{array}$ \\
\hline $\ln (A g e)_{i}$ & $\begin{array}{c}2.7906^{* *} \\
(1.242)\end{array}$ & $\begin{array}{c}4.7471^{* * * *} \\
(1.0369)\end{array}$ & $\begin{array}{c}-2.0218^{* * * *} \\
(0.242)\end{array}$ \\
\hline $\ln (A g e)_{i}^{2}$ & $\begin{array}{c}-0.480^{* * * *} \\
(0.174)\end{array}$ & $\begin{array}{c}-0.7707^{* * *} \\
(0.145)\end{array}$ & - \\
\hline$N_{o}{ }$ child $_{i}$ & $\begin{array}{l}-0.0843 \\
(0.077)\end{array}$ & $\begin{array}{l}-0.0724 \\
(0.064)\end{array}$ & $\begin{array}{c}-0.2951 \\
(0.240)\end{array}$ \\
\hline School $_{i}$ & $\begin{array}{l}0.0217 \\
(0.052)\end{array}$ & $\begin{array}{l}0.0495 \\
(0.044)\end{array}$ & $\begin{array}{l}0.1362 \\
(0.173)\end{array}$ \\
\hline College $_{i}$ & $\begin{array}{l}0.0049 \\
(0.053)\end{array}$ & $\begin{array}{l}0.0411 \\
(0.045)\end{array}$ & $\begin{array}{l}0.0884 \\
(0.175)\end{array}$ \\
\hline Bachelor & & Base group & \\
\hline Master $_{i}$ & $\begin{array}{c}0.1296^{* * *} \\
(0.047)\end{array}$ & $\begin{array}{c}0.0919^{* *} \\
(0.039)\end{array}$ & $\begin{array}{c}0.3478^{* *} \\
(0.148)\end{array}$ \\
\hline$P h D_{i}$ & $\begin{array}{l}0.1127 \\
(0.077)\end{array}$ & $\begin{array}{l}0.0589 \\
(0.064)\end{array}$ & $\begin{array}{l}0.1631 \\
(0.231)\end{array}$ \\
\hline Female $_{i}$ & $\begin{array}{c}-0.0983^{* * *} \\
(0.035)\end{array}$ & $\begin{array}{c}-0.0824^{* * *} \\
(0.029)\end{array}$ & $\begin{array}{c}-0.3016^{* * *} \\
(0.113)\end{array}$ \\
\hline Engaged $_{i}$ & $\begin{array}{l}0.1282 \\
(0.099)\end{array}$ & $\begin{array}{l}0.0773 \\
(0.083)\end{array}$ & $\begin{array}{l}0.5582^{*} \\
(0.326)\end{array}$ \\
\hline Single & & Base group & \\
\hline Married $_{i}$ & $\begin{array}{r}-0.0745 \\
(0.079) \\
\end{array}$ & $\begin{array}{c}-0.0202 \\
(0.066) \\
\end{array}$ & $\begin{array}{r}-0.0547 \\
(0.249) \\
\end{array}$ \\
\hline Widowed $_{i}$ & $\begin{array}{l}-0.1479 \\
(0.111)\end{array}$ & $\begin{array}{c}-0.1589^{*} \\
(0.093)\end{array}$ & $\begin{array}{c}-0.3129 \\
(0.345)\end{array}$ \\
\hline$C$ & $\begin{array}{l}-2.8116 \\
(2.267)\end{array}$ & $\begin{array}{c}-6.0354^{* * *} \\
(1.893)\end{array}$ & $p_{c}<0.01$ \\
\hline No. of Inc. Obs. & 1118 & 1118 & 1118 \\
\hline R / $\mathrm{R}_{\mathrm{w}} /$ Pseudo R-Squared & 0.188 & 0.332 & 0.065 \\
\hline
\end{tabular}

Note: ${ }^{* * *}, *^{* *}$, and ${ }^{*}$ denote statistical significance at 1\%, 5\%, and 10\%, respectively. Standard errors are in parameters.

a Dependent variable is $\ln (I E)_{i}$.

${ }^{b}$ Dependent variable is $\ln (I E)_{i}$.Method: M-estimation. $M$ settings: weight=Bisquare, tuning=4.685, scale $=$ MAD (median centered), Huber Type I Standard Errors \& Covariance.

${ }^{c}$ Dependent variable is $\ln \left(\frac{p}{1-p}\right)_{i}$. Number of ordered indicator values: 7 . Convergence achieved after 5 iterations. Coefficient covariance computed using observed Hessian.

The threshold value of LS is 7.3 for OLS and 7.69 for Robust LS - very close to each other. Note that LS varies between 5 and 35, and those within 5-9 LS score is considered to be extremely dissatisfied with life. LS value at the threshold point is near to the minimum level. The result means that the impact of self-reported life satisfaction on emigration intention is relatively positive (very close to zero) among the most extremely dissatisfied individuals in 
Azerbaijan. However, the impact turns to be negative as life satisfaction increases. Not surprisingly, the negative impact is more prominent at a higher level of self-reported life satisfaction. Overall, results support the hypothesis of "unhappy moves" for migration in the minds of Azerbaijan citizens. Life satisfaction increase causes to a decrease in intention to emigration. Ordered-Logit provides a similar outcome, which confirms the robustness of our empirical results.

Beyond life satisfaction, empirical results also allow being informed about other determinants of intention to emigration among the employed people in the country. It is found that earnings (hourly salary) have an insignificant negative impact ( $p>0.1$ ) which confirm the limited role of monetary motives. In contrast, increasing job satisfaction decreases emigration aspirations. The impact is negative and statistically significant in all estimated models $(p<0.05)$. Therefore, policies towards enhancing job satisfaction will decrease the intention to emigrate in the country.

Regarding the role of individual-specific factors, results display an insignificant negative impact of having children $(p>0.1)$. Marital status also does not significantly matter $(p>0.1)$. Only engaged and single people are relatively more prone to emigrate. Meanwhile, it is revealed that the emigration aspirations of females are significantly less than males $(p<$ 0.01 ), which is quite understandable when travelling constraints of females in a primarily Muslim society is considered. Simultaneously, OLS and Robust LS conclude that the impact of age over the intention to emigrate is inverse U-shaped while Ordered Logit presents a significant negative association. Similar to equation (3-5) and (6-9), calculated threshold levels of age for OLS and Robust LS are 18.29 and 21.75, respectively. The result implies that higher emigration aspirations at a younger age decreases as getting older.

\subsection{Robustness check}

Empirical results in Table 2 are single equation-based. To check robustness of the results, a step-by-step modelling approach is applied to estimate the equation (2). All results are given in Appendix B1-B3 at the end. At the first stage, the baseline model, including only life satisfaction as the independent variable, is estimated, while the second model also includes the age of the respondents. Job-related factors $\left(A J C_{i}\right.$ and $\left.\ln (H S)_{i}\right)$ are added to the functional specification in the 3rd model. At the 4thstage, educational dummies are added. Final specification (results displayed in table 2) additionally includes gender, having any child or not and marital status-related dummies.

In all specifications, findings are very close to each other. Regardless of the specification, LS-IE and age-IE relationships are found to be U-shaped by OLS and Robust LS, while Ordered Logit finds negative association. The threshold level of LS changes between 6.22-7.69 at different model specifications, which are almost identically the same. Simultaneously, threshold level of age is around the twenties in all cases. All these confirm the robustness of the results.

\section{Conclusion}

Emigration can be comprehended as efforts for getting better life conditions and opportunities. According to many researchers, life satisfaction is one of the leading factors cause to intention to emigrate. Though some studies (Glover, 2001; Lapshyn and Düvell, 2015; Ivlevs, 2015; Simpson, 2017; Ozaltin et al., 2019) indicating that development in determinants of life satisfaction can positively affect the emigration decision, studies concluded with the existence of negative relationship are also found in existing literature 
(Polgreen and Simpson, 2011; Otrachshenko and Popova, 2014; Graham and Markowitz, 2011; Chindarkar, 2014, Cai et al., 2014). While the first group support validity of "happy moves", some other studies present evidence in favour of "unhappy moves" hypothesis.

Research findings altogether support the "unhappy moves" hypothesis, as expected. It becomes clear that extremely dissatisfied individuals are the most vulnerable to emigration, while the intention decreases with the rise in life satisfaction. Dominating unhappiness motive behind emigration intentions should have negative consequences for both Azerbaijan and migrant-receiving countries. In the home country context, unhappiness may trigger the emigration of the skilled labour force (brain drain), which is a significant loss for the country with limited high-skilled human capital. On the other hand, unhappy moves may create additional pressure on host societies, as underlined by Ivlevs (2015).

Contrary to Clement's (2014) findings, we do not find a significant impact of earnings on intention to emigrate. Here, included another factor - agreement with job conditions should be considered, which have a significant impact on the emigration intention of individuals. Therefore, the impact of job-related factors is represented mostly by undesirable working conditions that psychologically cover personal earnings.

Empirical results help to suggest numerous policy recommendations for the government of Azerbaijan Republic to overcome difficulties related to emigration intentions in the society. Current research determines three primary factors (life satisfaction, age, job conditions) which can be at the policy focus. The government should collaborate with independent agencies, collect more information and determine major factors affecting the life satisfaction of individuals in the society. Increasing earnings level may be a solution at lower income group only. Aliyev, Dehning and Nadirov (2021) identify income-life satisfaction relationship as a wave in Azerbaijan.

Regarding the higher emigration intention among youth, the government should create more opportunities and a healthy environment for the young people. Various state programs and competitions can be used to enhance life satisfaction and decrease emigration intention among youth. Regarding working conditions, there is a very limited passive role of the labour union in the Azerbaijan market. The development of labour unions may solve the problem at some level.

The major limitation of the current research is excluding the non-working population in the analyses. Especially, unemployed people should be considered less satisfied (Aliyev, 2021), which implies being more vulnerable to emigration aspirations. Therefore, future research should include unemployed people into analyses as well.

\section{Acknowledgement}

This research received no specific grant from any funding agency in the public, commercial, or not-for-profit sectors.

\section{References}

Allahveranov, A., Aliyeva, R., \& Sadigov, T. (2012). Social Impact of Emigration and RuralUrban Migration in Central and Eastern Europe. Executive Summary: Azerbaijan.

Aliyev, K., \& Gasimov, I. (2018). Fiscal policy implementation in Azerbaijan before, during and after the oil boom. Contemporary Economics, 12(1), 81-94.

Aliyev, K. (2021). Unhappiness and unemployment: Who are the most vulnerable in Azerbaijan?. Submitted to Journal of International Studies. Under review. 
Aliyev, K., Dehning, B. \& Nadirov, O. (2021). Income and life satisfaction: a 'wave formation' framework. Journal of Happiness Studies, 1-14.

Angelini, V., Casi, L., \& Corazzini, L. (2015). Life satisfaction of immigrants: Does cultural assimilation matter?. Journal of Population Economics, 28(3), 817-844.

ASERC. (2018). Social Survey -2. Unpublished dataset.

Bartram, D. (2011). Economic migration and happiness: Comparing immigrants' and natives' happiness gains from income. Social Indicators Research, 103(1), 57-76.

Bertoli, S., \& Ruyssen, I. (2018). Networks and migrants' intended destination. Journal of Economic Geography, 18(4), 705-728.

Black, R., Natali, C., \& Skinner, J. (2005). Migration and Inequality. Development Research Centre on Migration, Globalization and Poverty. University of Sussex

Bloeser, A. J., McCurley, C., \& Mondak, J. J. (2012). Jury service as civic engagement: Determinants of jury summons compliance. American Politics Research, 40(2), 179204.

Cai, R., Esipova, N., Oppenheimer, M., \& Feng, S. (2014). International migration desires related to subjective well-being. IZA Journal of Migration, 3(1), 8.

Canache, D., Hayes, M., Mondak, J. J., \& Wals, S. C. (2013). Openness, extraversion and the intention to emigrate. Journal of Research in Personality, 47(4), 351-355.

Carling, J. (2017). "How Does Migration Arise?", in M. McAuliffe and M. Klein Solomon (Conveners) (2017). Ideas to Inform International Cooperation on Safe, Orderly and Regular Migration, IOM, Geneva., 19-26.

Carling, J., \& Schewel, K. (2018). Revisiting aspiration and ability in international migration. Journal of Ethnic and Migration Studies, 44(6), 945-963.

Cárdenas, M., Di Maro, V., \& Sorkin, I. (2009). Migration and life satisfaction: Evidence from Latin America. Journal of Business Strategies, 26(1), 9-33.

Chindarkar, N. (2014). Is subjective well-being of concern to potential migrants from Latin America?. Social indicators research, 115(1), 159-182.

Clemens, M. A. (2014). Does development reduce migration. International Handbook on migration and Economic development, 152.

Clemens, M. A. (2017). Migration is a Form of Development: The Need for Innovation to Regulate Migration for Mutual Benefit. Center for Global Development and IZA Institute of Labour Economics, December.

Cooray, A., \& Schneider, F. (2016). Does corruption promote emigration? An empirical examination. Journal of Population Economics, 29(1), 293-310.

De Jong, G. F., Chamratrithirong, A., \& Tran, Q. G. (2002). For Better, For Worse: Life Satisfaction Consequences of Migration 1. International Migration Review, 36(3), 838863.

De, H. H. (2010). Migration and Development: A Theoretical Perspective. The International migration review, 44(1), 227-264.

Diener, E., Lucas, R., Helliwell, J. F., Helliwell, J., \& Schimmack, U. (2009). Well-being for public policy. Series in Positive Psychology.

Dimant, E., Krieger, T., \& Meierrieks, D. (2013). The effect of corruption on migration, 1985-2000. Applied Economics Letters, 20(13), 1270-1274.

Docquier, F., Peri, G., \& Ruyssen, I. (2014). The cross-country determinants of potential and actual migration. International Migration Review, 48, 37-99.

Hăisan, A. A., Goschin, Z., \& Avornicului, M. (2017). Understanding the emigration propensity of Romanian teachers: Does ethnicity play a role?. Acta Oeconomica, 67(2), 173-193. 
Hiskey, J., Montalvo, J. D., \& Orcés, D. (2014). Democracy, governance, and emigration intentions in Latin America and the Caribbean. Studies in Comparative International Development, 49(1), 89-111.

Iunusov, A. S. (2003). Migration in Post-Soviet Azerbaijan. Russian Politics \& Law, 41(3), 69-83.

Ivlevs, A. (2014). Happiness and the emigration decision. IZA World of Labor. Retrieved from http://wol.iza.org/articles/happiness-and-the-emigration-decision , 10.07.2019

Ivlevs, A. (2015). Happy moves? Assessing the link between life satisfaction and emigration intentions. Kyklos, 68(3), 335-356.

Glover, S., Gott, C., Loizillon, A., Portes, J., Price, R., Spencer, S., Srinivasan V., \& Willis, C. (2001). Migration: an economic and social analysis. Research Development and Statistics Directorate.

Graham, C., \& Markowitz, J. (2011). Aspirations and happiness of potential Latin American immigrants. Journal of Social Research \& Policy, 2(2), 9.

Gugushvili, A. (2011). Democratic Discontent and Emigration: Do Political Attitudes Explain Emigration Intentions. Mimeo, European University Institute.

Kuo, B. C., \& Roysircar, G. (2006). An exploratory study of cross-cultural adaptation of adolescent Taiwanese unaccompanied sojourners in Canada. International Journal of Intercultural Relations, 30(2), 159-183.

Lapshyna, I., \& Düvell, F. (2015). Migration, life satisfaction, return and development: the case of a deprived post-Soviet country (Ukraine). Migration and Development, 4(2), 291-310.

Lönnqvist, J. E., Leikas, S., Mähönen, T. A., \& Jasinskaja-Lahti, I. (2015). The mixed blessings of migration: Life satisfaction and self-esteem over the course of migration. European Journal of Social Psychology, 45(4), 496-514.

Manchin, M., \& Orazbayev, S. (2018). Social networks and the intention to migrate. World Development, 109, 360-374.

Melzer, S. M. (2011). Does Migration Make You Happy? The Influence of Migration on Subjective Well-Being. Journal of Social Research \& Policy, 2(2), 73-92.

Migali, S., \& Scipioni, M. (2018). A global analysis of intentions to migrate. European Commission, JRC111207.

Nowok, B., Van Ham, M., Findlay, A. M., \& Gayle, V. (2013). Does migration make you happy? A longitudinal study of internal migration and subjective wellbeing. Environment and Planning A, 45(4), 986-1002.

Olgiati, A., Calvo, R., \& Berkman, L. (2013). Are migrants going up a blind alley? Economic migration and life satisfaction around the world: Cross-national evidence from Europe, North America and Australia. Social Indicators Research, 114(2), 383-404.

Orosová, O., Benka, J., Hricová, L., \& Kulanová, M. (2018). Gender, Rootedness, Normative Beliefs and Emigration Intentions of Slovak University Students. International Migration, 56(4), 172-196.

Otrachshenko, V., \& Popova, O. (2014). Life (dis) satisfaction and the intention to migrate: Evidence from Central and Eastern Europe. The Journal of Socio-Economics, 48, 40-49.

Ozaltin, D., Shakir, F., \& Loizides, N. (2019). Why Do People Flee? Revisiting Forced Migration in Post-Saddam Baghdad. Journal of International Migration and Integration, 21, 1-24.

Papapanagos, H., \& Sanfey, P. (2001). Intention to emigrate in transition countries: the case of Albania. Journal of Population Economics, 14(3), 491-504.

Polgreen, L. A., \& Simpson, N. B. (2011). Happiness and international migration. Journal of Happiness Studies, 12(5), 819-840. 
Radnitz, S. (2006). What really happened in Kyrgyzstan?. Journal of Democracy, 17(2), 132146.

Simpson, N.B. (2017). Demographic and economic determinants of migration; Push and pull factors drive the decision to stay or move. IZA World of Labor, June 2017

Steiner, I. (2019). Settlement or mobility? Immigrants' re-migration decision-making process in a high-income country setting. Journal of International Migration and Integration, 20(1), 223-245.

Switek, M. (2016). Internal migration and life satisfaction: Well-being paths of young adultmigrants. Social Indicators Research, 125(1), 191-241.

Szilasi, B. S., \& Halász, L. (2018). Reasons and Characteristics of the Dynamizing Emigration Intention of the Hungarian Youth. Eastern European Business and Economics Journal, 4 (1-special issue Hungarian youth mobility in Europe), 79-96.

Tabuga, Aubrey D. (2018). Analyzing Decisiveness of Migration Intentions: Social Kinship that Matters. No. DP 2018-06. Philippine Institute for Development Studies, 2018.

Tjaden, J., Auer, D., \& Laczko, F. (2019). Linking Migration Intentions with Flows: Evidence and Potential Use. International Migration, 57(1), 36-57.

Worlddata. (2020). Asylum applications and refugees from Azerbaijan. https://www.worlddata.info/asia/azerbaijan/asylum.php (Accessed 01.07.2021)

Ying, Y. W. (2005). Variation in acculturative stressors over time: A study of Taiwanese students in the United States. International Journal of Intercultural Relations, 29(1), $59-71$. 


\section{Appendix}

Appendix A: Distribution of emigration intention in Azerbaijan

\begin{tabular}{|c|c|c|c|c|c|c|c|c|}
\hline & $\begin{array}{l}\text { Strongly } \\
\text { disagree }\end{array}$ & Disagree & $\begin{array}{c}\text { Slightly } \\
\text { disagree }\end{array}$ & Neutral & $\begin{array}{c}\text { Slightly } \\
\text { agree }\end{array}$ & Agree & $\begin{array}{c}\text { Totally } \\
\text { agree }\end{array}$ & Total \\
\hline Total & 116 & 193 & 32 & 116 & 144 & 246 & 455 & 1302 \\
\hline$\%$ of & $9 \%$ & $15 \%$ & $2 \%$ & $9 \%$ & $11 \%$ & $19 \%$ & $35 \%$ & $100 \%$ \\
\hline
\end{tabular}

Intention to emigrate by gender

\begin{tabular}{|c|c|c|c|c|c|c|c|c|}
\hline Male & 58 & 87 & 20 & 60 & 83 & 138 & 261 & 707 \\
\hline$\%$ of & $8 \%$ & $12 \%$ & $3 \%$ & $8 \%$ & $12 \%$ & $20 \%$ & $37 \%$ & $100 \%$ \\
\hline Female & 58 & 106 & 12 & 56 & 61 & 108 & 194 & 595 \\
\hline$\%$ of & $10 \%$ & $18 \%$ & $2 \%$ & $9 \%$ & $10 \%$ & $18 \%$ & $33 \%$ & $100 \%$ \\
\hline
\end{tabular}

Intention to emigrate across age groups

\begin{tabular}{|c|c|c|c|c|c|c|c|c|}
\hline $17-24$ & 17 & 28 & 8 & 34 & 44 & 71 & 184 & 386 \\
\hline$\%$ of & $5 \%$ & $7 \%$ & $2 \%$ & $9 \%$ & $11 \%$ & $18 \%$ & $48 \%$ & $100 \%$ \\
\hline $25-34$ & 35 & 56 & 8 & 44 & 50 & 93 & 181 & 467 \\
\hline$\%$ of & $7 \%$ & $12 \%$ & $2 \%$ & $9 \%$ & $11 \%$ & $20 \%$ & $39 \%$ & $100 \%$ \\
\hline $35-44$ & 22 & 32 & 10 & 22 & 28 & 41 & 48 & 203 \\
\hline$\%$ of & $11 \%$ & $16 \%$ & $5 \%$ & $11 \%$ & $14 \%$ & $20 \%$ & $23 \%$ & $100 \%$ \\
\hline $45-65$ & 40 & 74 & 6 & 16 & 22 & 40 & 38 & 236 \\
\hline$\%$ of & $17 \%$ & $31 \%$ & $3 \%$ & $7 \%$ & $9 \%$ & $17 \%$ & $16 \%$ & $100 \%$ \\
\hline $25-65$ & 95 & 162 & 24 & 82 & 98 & 173 & 266 & 900 \\
\hline$\%$ of & $10 \%$ & $18 \%$ & $3 \%$ & $9 \%$ & $11 \%$ & $19 \%$ & $30 \%$ & $100 \%$ \\
\hline
\end{tabular}

Intention to emigrate vs educational attainment level

\begin{tabular}{|c|c|c|c|c|c|c|c|c|}
\hline School & 22 & 29 & 4 & 16 & 10 & 45 & 88 & 214 \\
\hline$\%$ of & 10.3 & 13.5 & 1.87 & 7.48 & 4.67 & 21.03 & 41.15 & 100 \\
\hline College & 21 & 34 & 2 & 8 & 13 & 34 & 65 & 177 \\
\hline$\%$ of & 11.86 & 19.21 & 1.13 & 4.52 & 7.34 & 19.21 & 36.73 & 100 \\
\hline Bachelor & 55 & 86 & 14 & 64 & 66 & 99 & 213 & 597 \\
\hline$\%$ of & 9.21 & 14.41 & 2.34 & 10.72 & 11.06 & 16.58 & 35.68 & 100 \\
\hline Master & 13 & 33 & 5 & 22 & 34 & 61 & 76 & 244 \\
\hline$\%$ of & 5.33 & 13.52 & 2.05 & 9.02 & 13.93 & 25 & 31.15 & 100 \\
\hline $\mathrm{PhD}$ & 5 & 11 & 7 & 6 & 21 & 7 & 13 & 70 \\
\hline$\%$ of & 7.14 & 15.71 & 10 & 8.57 & 30 & 10 & 18.58 & 100 \\
\hline
\end{tabular}

Source: Authors' own completion from survey data 
Appendix B1. OLS results

\begin{tabular}{|c|c|c|c|c|c|}
\hline $\begin{array}{c}\text { Independent } \\
\text { variables }\end{array}$ & (1) & (2) & (3) & (4) & (5) \\
\hline $\ln (L S)_{i}$ & $\begin{array}{c}0.8056^{* *} \\
(0.504)\end{array}$ & $\begin{array}{c}0.6991^{* *} \\
(0.360)\end{array}$ & $\begin{array}{c}0.8359^{* *} \\
(0.390)\end{array}$ & $\begin{array}{c}0.7748^{* *} \\
(0.391)\end{array}$ & $\begin{array}{c}0.8352^{* *} \\
(0.390)\end{array}$ \\
\hline $\ln (L S)_{i}^{2}$ & $\begin{array}{c}-0.2179^{* * * *} \\
(0.383) \\
\end{array}$ & $\begin{array}{c}-0.1911^{* * *} \\
(0.067) \\
\end{array}$ & $\begin{array}{c}-0.2097^{* * *} \\
(0.073)\end{array}$ & $\begin{array}{c}-0.1996^{* * * *} \\
(0.073)\end{array}$ & $\begin{array}{c}-0.2101^{* * * *} \\
(0.073)\end{array}$ \\
\hline $\ln (A g e)_{i}$ & - & $\begin{array}{c}2.5554^{* * * *} \\
(0.958)\end{array}$ & $\begin{array}{c}3.2443^{* * * *} \\
(1.128)\end{array}$ & $\begin{array}{l}2.7869^{* *} \\
(1.155)\end{array}$ & $\begin{array}{c}2.7906^{* *} \\
(1.242)\end{array}$ \\
\hline $\ln (A g e)_{i}^{2}$ & - & $\begin{array}{c}-0.4492^{* * *} \\
(0.137) \\
\end{array}$ & $\begin{array}{c}-0.5451^{* * *} \\
(0.161) \\
\end{array}$ & $\begin{array}{c}-0.4811^{* * * *} \\
(0.164) \\
\end{array}$ & $\begin{array}{c}-0.480^{* * * *} \\
(0.174) \\
\end{array}$ \\
\hline$A J C_{i}$ & - & - & $\begin{array}{c}-0.0255^{* *} \\
(0.011)\end{array}$ & $\begin{array}{c}-0.0267^{* * *} \\
(0.011)\end{array}$ & $\begin{array}{c}-0.0268^{* * *} \\
(0.011)\end{array}$ \\
\hline $\ln (H S)_{i}$ & - & - & $\begin{array}{l}0.0176 \\
(0.021)\end{array}$ & $\begin{array}{c}0.003 \\
(0.023)\end{array}$ & $\begin{array}{l}-0.0067 \\
(0.023)\end{array}$ \\
\hline School $_{i}$ & - & - & - & $\begin{array}{l}0.0332 \\
(0.052)\end{array}$ & $\begin{array}{l}0.0217 \\
(0.052)\end{array}$ \\
\hline College $_{i}$ & - & - & - & $\begin{array}{l}-0.0067 \\
(0.053) \\
\end{array}$ & $\begin{array}{l}0.0049 \\
(0.053) \\
\end{array}$ \\
\hline Bachelor & & & use group & & \\
\hline Master $_{i}$ & - & - & - & $\begin{array}{c}0.1228^{* * *} \\
(0.046)\end{array}$ & $\begin{array}{c}0.1296^{* * *} \\
(0.047)\end{array}$ \\
\hline$P h D_{i}$ & - & - & - & $\begin{array}{l}0.1085 \\
(0.077)\end{array}$ & $\begin{array}{l}0.1127 \\
(0.077) \\
\end{array}$ \\
\hline Female $_{i}$ & - & - & - & - & $\begin{array}{c}-0.0983^{* * *} \\
(0.035)\end{array}$ \\
\hline Engaged $_{i}$ & - & - & - & - & $\begin{array}{l}0.1282 \\
(0.099) \\
\end{array}$ \\
\hline Single & & & se group & & \\
\hline Married $_{i}$ & - & - & - & - & $\begin{array}{l}-0.0745 \\
(0.079)\end{array}$ \\
\hline Widowed $_{i}$ & - & - & - & - & $\begin{array}{l}-0.1479 \\
(0.111)\end{array}$ \\
\hline No_child $_{i}$ & - & - & - & - & $\begin{array}{l}-0.0843 \\
(0.077) \\
\end{array}$ \\
\hline C & $\begin{array}{c}0.9716^{* *} \\
(0.504) \\
\end{array}$ & $\begin{array}{l}-2.380 \\
(1.741)\end{array}$ & $\begin{array}{c}-3.7616^{*} \\
(2.048) \\
\end{array}$ & $\begin{array}{l}-2.8531 \\
(2.098) \\
\end{array}$ & $\begin{array}{l}-2.8116 \\
(2.267) \\
\end{array}$ \\
\hline $\begin{array}{l}\text { No. of Inc. } \\
\text { Obs. }\end{array}$ & 1302 & 1298 & 1118 & 1118 & 1118 \\
\hline R Squared & 0.069 & 0.177 & 0.173 & 0.179 & 0.188 \\
\hline
\end{tabular}

Note: Dependent variable is $\ln (I E)_{i}{ }^{* * * *},{ }^{* *}$, and ${ }^{*}$ denote statistical significance at 1\%, 5\%, and 10\%, respectively. Standard errors are in parameters. 
Appendix B2. Robust LS results

\begin{tabular}{|c|c|c|c|c|c|}
\hline $\begin{array}{c}\text { Independent } \\
\text { variables }\end{array}$ & (1) & (2) & (3) & (4) & (5) \\
\hline $\ln (L S)_{i}$ & $\begin{array}{c}0.5794^{* *} \\
(0.246)\end{array}$ & $\begin{array}{c}0.5616^{* *} \\
(0.286)\end{array}$ & $\begin{array}{l}0.7945^{* *} \\
(0.322)\end{array}$ & $\begin{array}{c}0.7543^{* *} \\
(0.326)\end{array}$ & $\begin{array}{c}0.8076^{* *} \\
(0.326)\end{array}$ \\
\hline $\ln (L S)_{i}^{2}$ & $\begin{array}{c}-0.1541^{* * * *} \\
(0.046) \\
\end{array}$ & $\begin{array}{c}-0.1529^{* * * *} \\
(0.053) \\
\end{array}$ & $\begin{array}{c}-0.1952^{* * * *} \\
(0.060)\end{array}$ & $\begin{array}{c}-0.189^{* * *} \\
(0.061)\end{array}$ & $\begin{array}{c}-0.1979^{* * * *} \\
(0.061)\end{array}$ \\
\hline $\ln (A g e)_{i}$ & - & $\begin{array}{c}4.8659^{* * * *} \\
(0.760)\end{array}$ & $\begin{array}{c}5.3149^{* * * *} \\
(0.930)\end{array}$ & $\begin{array}{c}5.1421^{* * * *} \\
(0.964)\end{array}$ & $\begin{array}{c}4.7471^{* * *} \\
(1.0369)\end{array}$ \\
\hline $\ln (A g e)_{i}^{2}$ & - & $\begin{array}{c}-0.7819^{* * * *} \\
(0.108) \\
\end{array}$ & $\begin{array}{c}-0.8309^{* * * *} \\
(0.132) \\
\end{array}$ & $\begin{array}{c}-0.8222^{* * * *} \\
(0.137) \\
\end{array}$ & $\begin{array}{c}-0.7707^{* * * *} \\
(0.145) \\
\end{array}$ \\
\hline$A J C_{i}$ & - & - & $\begin{array}{c}-0.0231^{* *} \\
(0.009)\end{array}$ & $\begin{array}{c}-0.0237^{* * * *} \\
(0.009)\end{array}$ & $\begin{array}{c}-0.0234^{* * *} \\
(0.009)\end{array}$ \\
\hline $\ln (H S)_{i}$ & - & - & $\begin{array}{l}0.0083 \\
(0.017)\end{array}$ & $\begin{array}{l}0.0045 \\
(0.019)\end{array}$ & $\begin{array}{l}-0.0007 \\
(0.019)\end{array}$ \\
\hline School $_{i}$ & - & - & - & $\begin{array}{l}0.0601 \\
(0.044)\end{array}$ & $\begin{array}{l}0.0495 \\
(0.044) \\
\end{array}$ \\
\hline College $_{i}$ & - & - & - & $\begin{array}{l}0.0316 \\
(0.044)\end{array}$ & $\begin{array}{l}0.0411 \\
(0.045)\end{array}$ \\
\hline Bachelor & & & use group & & \\
\hline Master $_{i}$ & - & - & - & $\begin{array}{c}0.0782^{* *} \\
(0.039)\end{array}$ & $\begin{array}{c}0.0919^{* *} \\
(0.039)\end{array}$ \\
\hline$P h D_{i}$ & - & - & - & $\begin{array}{l}0.0636 \\
(0.064) \\
\end{array}$ & $\begin{array}{l}0.0589 \\
(0.064) \\
\end{array}$ \\
\hline Female $_{i}$ & - & - & - & - & $\begin{array}{c}-0.0824^{* * *} \\
(0.029)\end{array}$ \\
\hline Engaged $_{i}$ & - & - & - & - & $\begin{array}{l}0.0773 \\
(0.083) \\
\end{array}$ \\
\hline Single & & & se group & & \\
\hline Married $_{i}$ & - & - & - & - & $\begin{array}{l}-0.0547 \\
(0.249) \\
\end{array}$ \\
\hline Widowed $_{i}$ & - & - & - & - & $\begin{array}{l}-0.3129 \\
(0.345) \\
\end{array}$ \\
\hline No_child $_{i}$ & - & - & - & - & $\begin{array}{c}-0.0724 \\
(0.064) \\
\end{array}$ \\
\hline C & $\begin{array}{c}1.3227^{* * *} \\
(0.324)\end{array}$ & $\begin{array}{c}-6.1332^{* * *} \\
(1.381) \\
\end{array}$ & $\begin{array}{c}-6.9835^{* * * *} \\
(1.689) \\
\end{array}$ & $\begin{array}{c}-6.7967^{* * *} \\
(1.750) \\
\end{array}$ & $\begin{array}{c}-6.0354^{* * * *} \\
(1.893) \\
\end{array}$ \\
\hline $\begin{array}{l}\text { No. of Inc. } \\
\text { Obs. }\end{array}$ & 1302 & 1298 & 1118 & 1118 & 1118 \\
\hline Rw- Squared & 0.105 & 0.323 & 0.316 & 0.321 & 0.332 \\
\hline
\end{tabular}

Note: Dependent variable is $\ln (I E)_{i} .{ }^{* * *},{ }^{* *}$, and ${ }^{*}$ denote statistical significance at $1 \%, 5 \%$, and $10 \%$, respectively. Standard errors are in parameters. Method: $M$-estimation. $M$ settings: weight=Bisquare, tuning $=4.685$, scale $=$ MAD (median centered), Huber Type I Standard Errors \& Covariance. 
Appendix B3. Ordered Logit results

\begin{tabular}{|c|c|c|c|c|c|}
\hline $\begin{array}{c}\text { Independent } \\
\text { variables }\end{array}$ & (1) & (2) & (3) & (4) & (5) \\
\hline $\ln (L S)_{i}$ & $\begin{array}{c}-1.4215^{* * *} \\
(0.127)\end{array}$ & $\begin{array}{c}-1.4075^{* * *} \\
(0.128)\end{array}$ & $\begin{array}{c}-1.2839^{* * *} \\
(0.150)\end{array}$ & $\begin{array}{c}-1.3048^{* * *} \\
(0.151)\end{array}$ & $\begin{array}{c}-1.3124^{* * * *} \\
(0.152)\end{array}$ \\
\hline $\ln (A g e)_{i}$ & - & $\begin{array}{c}-1.8858^{* * * *} \\
(0.157) \\
\end{array}$ & $\begin{array}{c}-1.8364^{* * * *} \\
(0.175)\end{array}$ & $\begin{array}{c}-1.8446^{* * * *} \\
(0.178)\end{array}$ & $\begin{array}{c}-2.0218^{* * * *} \\
(0.242)\end{array}$ \\
\hline$A J C_{i}$ & - & - & $\begin{array}{c}-0.0853^{* *} \\
(0.037)\end{array}$ & $\begin{array}{c}-0.0849^{* *} \\
(0.037)\end{array}$ & $\begin{array}{c}-0.0818^{* *} \\
(0.037)\end{array}$ \\
\hline $\ln (H S)_{i}$ & - & - & $\begin{array}{l}0.0208 \\
(0.069) \\
\end{array}$ & $\begin{array}{l}-0.0018 \\
(0.074) \\
\end{array}$ & $\begin{array}{l}-0.0353 \\
(0.075) \\
\end{array}$ \\
\hline School $_{i}$ & - & - & - & $\begin{array}{l}0.1699 \\
(0.172)\end{array}$ & $\begin{array}{l}0.1362 \\
(0.173) \\
\end{array}$ \\
\hline College $_{i}$ & - & - & - & $\begin{array}{l}0.0558 \\
(0.173)\end{array}$ & $\begin{array}{l}0.0884 \\
(0.175)\end{array}$ \\
\hline Bachelor & & & use group & & \\
\hline Master $_{i}$ & - & - & - & $\begin{array}{c}0.3082^{* *} \\
(0.146) \\
\end{array}$ & $\begin{array}{c}0.3478^{* * *} \\
(0.148) \\
\end{array}$ \\
\hline$P h D_{i}$ & - & - & - & $\begin{array}{l}0.1671 \\
(0.232)\end{array}$ & $\begin{array}{l}0.1631 \\
(0.231)\end{array}$ \\
\hline Female $_{i}$ & - & - & - & - & $\begin{array}{c}-0.3016^{* * * *} \\
(0.113) \\
\end{array}$ \\
\hline Engaged $_{i}$ & - & - & - & - & $\begin{array}{l}0.5582^{*} \\
(0.326)\end{array}$ \\
\hline Single & & & se group & & \\
\hline Married $_{i}$ & - & - & - & - & $\begin{array}{l}-0.0547 \\
(0.249) \\
\end{array}$ \\
\hline Widowed $_{i}$ & - & - & - & - & $\begin{array}{l}-0.3129 \\
(0.345)\end{array}$ \\
\hline No_child $_{i}$ & - & - & - & - & $\begin{array}{l}-0.2951 \\
(0.240)\end{array}$ \\
\hline$C$ & $p_{c}<0.01$ & $p_{c}<0.01$ & $p_{c}<0.01$ & $p_{c}<0.01$ & $p_{c}<0.01$ \\
\hline $\begin{array}{l}\text { No. of Inc. } \\
\text { Obs. }\end{array}$ & 1302 & 1298 & 1118 & 1118 & 1118 \\
\hline $\begin{array}{l}\text { Pseudo R- } \\
\text { Squared }\end{array}$ & 0.030 & 0.064 & 0.061 & 0.062 & 0.065 \\
\hline
\end{tabular}

Note: Dependent variable is $\ln \left(\frac{p}{1-p}\right)_{i} .{ }^{* * *},{ }^{* *}$, and ${ }^{*}$ denote statistical significance at $1 \%, 5 \%$, and 10\%, respectively. Standard errors are in parameters. Number of ordered indicator values: 7. Convergence achieved after 5-7 iterations. Coefficient covariance computed using observed Hessian. 